Sebastian Garbe

Weaving Solidarity

Political Science | Volume 123 
This open access publication was enabled by the support of POLLUX - Informationsdienst Politikwissenschaft

POLLUXX Informationsdienst

and a network of academic libraries for the promotion of the open-access-transformation in the Social Sciences and Humanities (transcript Open Library Community Politik 2022).

Vollsponsoren: Freie Universität Berlin

- Universitätsbibliothek | Staatsbibliothek zu Berlin | Universitätsbibliothek der Humboldt-Universität zu Berlin | Universitätsbibliothek Bielefeld | Universitätsbibliothek der Ruhr-Universität Bochum | Universitäts- und Landesbibliothek Bonn | Staats- und Universitätsbibliothek Bremen | Universitäts- und Landesbibliothek Darmstadt | Sächsische Landesbibliothek Staats- und Universitätsbibliothek Dresden (SLUB) | Universitäts- und Landesbibliothek Düsseldorf | Universitätsbibliothek Frankfurt am Main | Justus-Liebig-Universität Gießen | Niedersächsische Staats- und Universitätsbibliothek Göttingen | Universitätsbibliothek der FernUniversität in Hagen | Staats- und Universitätsbibliothek Carl von Ossietzky, Hamburg | Gottfried Wilhelm Leibniz Bibliothek - Niedersächsische Landesbibliothek | Technische Informationsbibliothek (TIB Hannover) | Universitätsbibliothek Kassel | Universitätsbibliothek Kiel (CAU) | Universitätsbibliothek Koblenz - Landau | Universitäts- und Stadtbibliothek Köln | Universitätsbibliothek Leipzig | Universitätsbibliothek Marburg | Universitätsbibliothek der
Ludwig-Maximilians-Universität München | Max Planck Digital Library (MPDL) | Universität der Bundeswehr München | Universitäts- und Landesbibliothek Münster | Universitätsbibliothek Erlangen-Nürnberg | Bibliotheks- und Informationssystem der Carl von Ossietzky Universität Oldenburg | Universitätsbibliothek Osnabrück | Universitätsbibliothek Passau | Universitätsbibliothek Vechta | Universitätsbibliothek Wuppertal | Vorarlberger Landesbibliothek | Universität Wien Bibliotheks- und Archivwesen | Zentral- und Hochschulbibliothek Luzern | Universitätsbibliothek St. Gallen | Zentralbibliothek Zürich

Sponsoring Light: Bundesministerium der Verteidigung | ifa (Institut für Auslandsbeziehungen), Bibliothek | Landesbibliothek Oldenburg | Ostbayerische Technische Hochschule Regensburg, Hochschulbibliothek | ZHAW Zürcher Hochschule für Angewandte Wissenschaften, Hochschulbibliothek

Mikrosponsoring: Stiftung Wissenschaft und Politik (SWP) - Deutsches Institut für Internationale Politik und Sicherheit | Leibniz-Institut für Europäische Geschichte

Sebastian Garbe, born in 1986, works as a postdoctoral researcher at the University of Applied Sciences Fulda, where he is the coordinator of the Fulda Graduate Centre of Social Sciences. He also works as a researcher and lecturer at the Institute of Sociology at the Justus-Liebig University in Giessen. His teaching and research were awarded with the Dr.-Herbert-Stolzenberg-Award for the Study of Culture in 2017 and 2020. 
Sebastian Garbe

\section{Weaving Solidarity}

Decolonial Perspectives on Transnational Advocacy of and with the Mapuche 
Dissertation at the Faculty for Social Sciences and Cultural Studies, Justus-Liebig-University Giessen

Examiners: Prof. Dr. Encarnación Gutiérrez Rodríguez and Prof. Dr. Olaf Kaltmeier The publication of this dissertation was supported by the Dr.-Herbert-Stolzenberg Foundation

The research for this dissertation has been funded by the International Graduate Centre for the Study of Culture (GCSC)

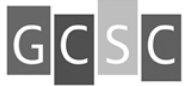

International Graduate Centre for the Study of Culture

\section{Bibliographic information published by the Deutsche Nationalbibliothek}

The Deutsche Nationalbibliothek lists this publication in the Deutsche Nationalbibliografie; detailed bibliographic data are available in the Internet at http://dnb.d-nb.de

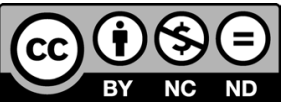

This work is licensed under the Creative Commons Attribution-NonCommercial-NoDerivatives 4.0 (BY-NC-ND) which means that the text may be used for non-commercial purposes, provided credit is given to the author. For details go to

http://creativecommons.org/licenses/by-nc-nd/4.o/

To create an adaptation, translation, or derivative of the original work and for commercial use, further permission is required and can be obtained by contacting rights@transcriptpublishing.com

Creative Commons license terms for re-use do not apply to any content (such as graphs, figures, photos, excerpts, etc.) not original to the Open Access publication and further permission may be required from the rights holder. The obligation to research and clear permission lies solely with the party re-using the material.

\section{() 2022 transcript Verlag, Bielefeld}

Cover layout: Maria Arndt, Bielefeld

Cover image: Performance "La Ruta de Kallfükura" by Alex Mora

Printed by Majuskel Medienproduktion $\mathrm{GmbH}$, Wetzlar

Print-ISBN 978-3-8376-5825-5

PDF-ISBN 978-3-8394-5825-9

EPUB-ISBN 978-3-7328-5825-5

https://doi.org/10.14361/9783839458259

ISSN of series: $2702-9050$

eISSN of series: 2702-9069

Printed on permanent acid-free text paper. 